\title{
Protecting Home Schooling through the Casey Undue Burden Standard
}

\author{
Jon S. Lerner $\dagger$
}

Home schooling is an enduring American tradition that counts Abraham Lincoln, Woodrow Wilson, and Thomas Edison among its most distinguished progeny. ${ }^{1}$ Although teaching children at home is still an uncommon alternative to public and private schools, the practice is growing. It is estimated that more than 300,000 elementary and secondary school age children were taught at home in $1992 .^{2}$

Society clearly has legitimate interests in the education of its youngest citizens. To protect those interests, states regulate home schooling just as they do conventional private schools. Unlike private schools, however, home schooling parents frequently find state requirements impossible to meet. When state standards effectively deny parents the opportunity to teach their children at home, the parents often assert that the state has infringed upon their constitutional rights.

The United States Supreme Court has held that the liberty interests protected by the Fourteenth Amendment extend to activities involving child rearing and education. ${ }^{3}$ It has not, Chicago.

† B.A. 1989, George Washington University; J.D. Candidate 1995, The University of

1 See Appeal of Peirce, 122 NH 762, 451 A2d 363, 367 (1982) (Douglas and Brock concurring) (citing Albert J. Beveridge, Abraham Lincoln 1809-1858 63 (Houghton Mifflin, 1928); Ray Stannard Baker, 1 Woodrow Wilson: Life and Letters 37 (Doubleday, Page, 1927); Matthew Josephson, Edison 20-23 (McGraw-Hill, 1959)).

2 David Guterson, Family Matters: Why Homeschooling Makes Sense 5 (Harcourt Brace Jovanovich, 1992). See also David W. Smith, Choosing Your Child's School 62 (Zondervan, 1991) (noting that his estimate of the current number of home schoolers, around 260,000 , has grown from approximately 15,000 in the 1970s). Other estimates are considerably higher. For example, the Home School Legal Defense Association estimates that there are between 400,000 and 1,000,000 home-schooled children in the country.

For another measure of the vibrancy of the home schooling movement, see Phil Kuntz, Home-Schooling Movement Gives House a Lesson, 52 Cong Q 479, 479 (Feb 26, 1994), recounting how home schooling supporters "overwhelmed the Capitol's phone system for days" in opposition to a teacher certification provision in the bill reauthorizing the Elementary and Secondary Education Act. The objectionable provision was defeated in the House of Representatives by a vote of 424 to 1 , and an amendment specifically safeguarding home schooling was approved 374 to 53 . Id at 480 .

${ }^{3}$ See, for example, Pierce $v$ Society of Sisters, 268 US 510, 534-35 (1925); Wisconsin $v$ 
however, decided a home schooling case; nor has it indicated that home schooling itself is a part of the liberty interest entitled to full Fourteenth Amendment protection. Consequently, lower courts have generally assessed state home schooling regulations under the low-level rational basis standard of review. ${ }^{4}$ In employing this standard, courts have routinely upheld state laws that severely restrict home schooling.

In 1992, the Supreme Court devised the undue burden standard, a new level of review occupying an intermediate position between the poles of rational basis and strict scrutiny. ${ }^{5}$ The Court applied the new standard to state regulation of abortion in Planned Parenthood of Southeastern Pennsylvania $v$ Casey, finding the undue burden standard to be a better way of balancing the state and private interests in the abortion context than either of the traditional standards of review. ${ }^{6}$

This Comment explores the application of the undue burden standard to home schooling regulations, including the reasons for employing such a standard, how it would be applied, and the impact it would have on current home schooling jurisprudence. Because the Comment attempts to apply a new standard in a different context, it frequently combines analysis of abortion and home schooling precedents and statutes, rather than keeping the two fields separate. Section I describes the undue burden standard and its purpose. It looks at the treatment of state abortion regulations under the traditional standards of review and the development of the undue burden standard as a way to balance the competing interests more evenly. Section II discusses the Supreme Court's child-rearing and education decisions and suggests similarities between these situations and the abortion context. Section III analyzes the various types of home schooling regulations and argues that many of them extend beyond the state's legitimate interests. Lastly, Section IV applies the undue burden standard to home schooling regulations. It examines classes of regulations that would remain intact under the new standard and those that would not. It also discusses one home schooling case in which the court's analysis closely approximated

\footnotetext{
Yoder, 406 US 205, 213-14 (1972).

4 Under the rational basis standard, courts will uphold laws that are rationally related to a valid state objective. See generally Laurence H. Tribe, American Constitutional Law 1439-43 (Foundation, 2d ed 1988).

5 To survive under the strict scrutiny standard, a law must serve a compelling state interest and be narrowly tailored to serve only that interest. See id at 1451-66.

6112 S Ct 2791, 2820 (1992).
} 
undue burden review. The Comment concludes that, when the state and parents clash, the undue burden standard provides a better means of protecting the Fourteenth Amendment liberty interests of home schooling parents and their children.

\section{The UNDUE BURDEN STANDARD AND ItS PURPOSE}

A. Competing Interests and Judicial Standards of Review in the Abortion Context

In treating this issue, the Supreme Court has long recognized that state regulation of abortion involves, at root, a conflict between two competing interests: the woman's interest in the freedom to terminate her pregnancy and the state's interest in protecting fetal life. Although the landmark abortion decision Roe $v$ Wade $^{7}$ is best known for establishing broad protection of abortion rights, the Court in Roe also recognized this underlying conflict. It stated that the "right [to abortion] is not unqualified and must be considered against important state interests in regulation." Justice Blackmun's majority opinion further held that "at some point [in a pregnancy] the state interests as to protection of health, medical standards, and prenatal life, become dominant."

The Roe Court attempted to balance these interests by dividing pregnancy into trimesters to demarcate the points at which private and state interests were "compelling." The Court held that the right to abortion was fundamental and worthy of the highest standard of review, strict scrutiny. Applying strict scrutiny in the abortion context meant that regulations limiting abortion had to be justified by a "compelling state interest" and drawn narrowly so as to give effect only to the legitimate state interests at issue. ${ }^{11}$

The Court rarely finds the compelling necessity required by the strict scrutiny standard. Indeed, the Court in Roe found no compelling state interest in potential life before the point of fetal viability, roughly at the end of the first two trimesters of pregnancy. Before this point, the abortion decision had to be "free of interference by the State." ${ }^{.12}$ According to the Court, regulations

${ }^{7} 410$ US 113 (1973).

Id at 154.

9 Id at 155.

10 Id at 162-63.

11 Id at 155.

12 Id at 163. 
protecting fetal life after viability were both logical and biologically justifiable. ${ }^{13}$ The critical point is that by adopting strict scrutiny, the Court precluded virtually all state regulation of abortion during the early stages of pregnancy, ceding dominance to private interests over those of the state.

Dissenting in Roe, then-Justice Rehnquist rejected the majority's use of strict scrutiny in favor of the more permissive rational basis standard of review, under which a law is constitutional as long as it is rationally related to a valid state objective. ${ }^{14}$ Such a standard would permit wider regulation of abortion even in the early stages of pregnancy. Under rational basis review, the balance tips heavily toward state interests and away from private interests.

Roe's central holding and its strict scrutiny standard were upheld in all thirteen abortion cases that the Court decided between 1976 and 1986. ${ }^{15}$ From 1986 to 1992, the Court upheld some restrictions on abortion but still left Roe and its standard of review largely undisturbed. ${ }^{16}$ In 1992, however, in Planned Parenthood of Southeastern Pennsylvania $v$ Casey, the Court discarded Roe's strict scrutiny of abortion regulations and replaced it with the "undue burden standard," a previously unknown, intermediate standard of review. ${ }^{17}$

\section{B. Casey and the Undue Burden Standard}

The genesis of the undue burden standard is found in Justice O'Connor's treatment of state abortion regulations. In abortion decisions prior to Casey, Justice O'Connor had criticized the Roe approach to balancing private and state interests and had articulated her preference for an undue burden standard..$^{18}$ This view,

13 Id.

14 Id at 173 (Rehnquist dissenting).

15 See Alan I. Bigel, Planned Parenthood of Southeastern Pennsylvania v. Casey: Constitutional Principles and Political Turbulence, 18 U Dayton L Rev 733, 735 (1993).

${ }^{16}$ See, for example, Webster $v$ Reproductive Health Services, 492 US 490, 521 (1989) (states have some compelling interests in viability that can be protected and regulated in the second trimester); Rust $v$ Sullivan, 500 US 173, 173-76 (1991) (federal funds may be withheld from family-planning agencies that discuss abortion as a method of family planning).

$17112 \mathrm{~S} \mathrm{Ct}$ at 2820.

${ }^{18}$ See, for example, City of Akron $v$ Akron Center for Reproductive Health, 462 US 416, 453 (1983) (O'Connor dissenting); Webster $v$ Reproductive Health Services, 492 US $490,529-30$ (1989) (O'Connor concurring in part and concurring in the judgment); Hodgson v Minnesota, 497 US 417, 459 (1990) (O'Connor concurring in part and concurring in the judgment in part). 
however, never formed the basis of a majority opinion in an abortion case, nor was it used in any other context. ${ }^{19}$ In her dissent in City of Akron $v$ Akron Center for Reproductive Health, Justice O'Connor explained her disagreement with Roe's trimester framework, stating her belief that the state's interest in protecting potential life existed throughout the entire pregnancy. She found the Roe approach "a completely unworkable method of accommodating the conflicting personal rights and compelling state interests that are involved in the abortion context."20

The novel undue burden standard was created, therefore, as a middle ground between the strict scrutiny standard, which favors private interests, and the rational basis standard, where state interests usually prevail. Proponents of Justice O'Connor's standard contended that it more adequately protects the interests of both parties. With the decision in Casey, this standard has come to control abortion jurisprudence.

Casey provides the most complete enunciation and the most elaborate criticism of the undue burden standard. ${ }^{21}$ In Casey, Justices O'Connor, Kennedy, and Souter all signed a joint opinion on behalf of a five-member majority, the first such joint decision from the Court since $1958 .^{22}$ The joint majority explicitly rejected the trimester framework of Roe, finding that "in practice it undervalues the State's interest in potential life, as recognized in Roe."23 Endorsing neither strict scrutiny nor rational basis review, the joint majority instead walked the line between these two standards, ultimately adopting the undue burden standard. The joint majority held that "[t]he very notion that the State has a substantial interest in potential life leads to the conclusion that not all regulations must be deemed unwarranted." ${ }^{24}$ Accordingly,

19 Justice O'Connor did, however, use an intermediate standard of review similar to that of the undue burden standard in another privacy area. See Justice O'Connor's opinion for a unanimous Court in Turner $v$ Safley, 482 US 78, 95 (1987), holding that the right to marry is subject to substantial restrictions in the face of important state interests-in this case, the regulation of prisons.

20462 US at 454 (O'Connor dissenting).

21 At issue was the constitutional validity of various provisions of the Pennsylvania Abortion Control Act of 1982, $18 \mathrm{~Pa}$ Cons Stat Ann $\$ \S 3203-20$ (Purdon 1983 \& Supp 1994), which required, inter alia, spousal notification, parental consent for minors, a twenty-four-hour waiting period, and disclosure of information about the probable gestational age of the fetus. See $112 \mathrm{~S} \mathrm{Ct}$ at $2803,2833$.

${ }_{22}$ See Bigel, $18 \mathrm{U}$ Dayton $\mathrm{L}$ Rev at 743 (cited in note 15). A joint opinion is one in which more than one Justice actually signs the opinion; a typical opinion is signed only by the single author, even when writing for several members of the Court. Id.

$23112 \mathrm{~S} \mathrm{Ct}$ at 2818.

24 Id at 2820 . 
"[o]nly where state regulation imposes an undue burden on a woman's ability to make this decision does the power of the State reach into the heart of the liberty protected by the Due Process Clause."25 In a critical passage providing the few discernable guidelines for the standard, the joint majority defined the standard as follows: "A finding of an undue burden is a shorthand for the conclusion that a state regulation has the purpose or effect of placing a substantial obstacle in the path of a woman seeking an abortion of a nonviable fetus."26 The task of a court, therefore, was to determine whether the regulation at issue erected such an obstacle.

The undue burden standard is not simply a midpoint between strict scrutiny and rational basis review. It is, more precisely, a threshold inquiry designed to establish whether the rational basis or strict scrutiny standard should be applied to a particular regulation. If a court determines that a law does not present an undue burden, it is to consider the law under the rational basis standard; but if a statute does create an undue burden, the court should apply strict scrutiny analysis. In the previability abortion context, this means that a regulation that does not create a substantial obstacle to a woman's ability to obtain an abortion will be constitutional as long as it is rationally related to a legitimate state interest. Thus, the undue burden standard is a noncoercion doctrine: it allows state regulation of abortion, but it forbids the state from either prohibiting abortion or taking steps that make abortions substantially more difficult to obtain. In examining the regulations of the Pennsylvania Abortion Control Act, the joint majority in Casey found that only one of five challenged provisions-the spousal notification requirement-failed to satisfy the new undue burden standard. Because this provision did have the effect of placing a substantial obstacle in a woman's path, it was unconstitutional. ${ }^{27}$

Theoretically, at least, the undue burden standard provides greater protection for state interests than does the strict scrutiny test, under which none of the Pennsylvania provisions would have been sustained. ${ }^{28}$ At the same time, it also protects private interests to a greater degree than does the rational basis stan-

25 Id at 2819.

26 Id at 2820 (emphasis added).

27 Id at 2829-30.

28 Indeed, this was Justice Blackmun's position in Casey, where he applied the strict scrutiny standard and rejected all provisions of the Pennsylvania law. Id at 2850 (Blackmun concurring in part, concurring in the judgment in part, and dissenting in part). 
dard, which would have permitted all the provisions of the Pennsylvania law to survive. ${ }^{29}$

The undue burden standard is not, of course, without its detractors. The dissenters in Casey attacked the very flexibility that the proponents of the new standard hailed. The Chief Justice charged that it lacked any recognized basis in constitutional law and had been "created largely out of whole cloth by the authors of the joint opinion." ${ }^{30}$ Justice Scalia found the standard "inherently manipulable," "hopelessly unworkable in practice," and merely a way to "conceal raw judicial policy choices concerning what is 'appropriate' abortion legislation." ${ }^{31}$ Commentators have agreed that the inherent ambiguity of the standard, caused by the absence of any definition of what burden is "undue," renders it an inevitable source of future litigation. They predict, moreover, that the Court will be forced to play an active role in clarifying the guidelines for applying the standard. ${ }^{32}$

\section{Constitutional Protection of Home Schooling}

Although the Supreme Court has never directly addressed the subject of home schooling, its decisions respecting parental authority over child-rearing and education choices suggest that some level of constitutional protection for home schooling is required. The Court's treatment of the personal liberty interests protected by the Fourteenth Amendment's Due Process Clause furnishes a coherent way of analyzing home schooling regulations that implicate parental liberty. Finally, the same reasoning that leads to the conclusion that home schooling is constitutionally protected also suggests that the undue burden standard provides the appropriate level of protection for home schooling.

\section{A. Links to Abortion and the Privacy Rights Umbrella}

Because abortion and home schooling have little outwardly to do with one another, it might appear at first glance that an anal-

29 This was the standard chosen by Chief Justice Rehnquist and Justice Scalia in their dissents. Id at 2867 (Rehnquist concurring in the judgment in part and dissenting in part); id at 2873-75 (Scalia concurring in the judgment in part and dissenting in part).

${ }^{30}$ Id at 2866 (Rehnquist concurring in the judgment in part and dissenting in part).

${ }^{31}$ Id at 2877-78 (Scalia concurring in the judgment in part and dissenting in part).

${ }^{32}$ See Bigel, 18 U Dayton L Rev at 762 (cited in note 15); Robert H. Bork, Again, A Struggle For The Soul Of The Court, NY Times A19 (July 8, 1992) (op-ed). See also David A. Strauss, Abortion, Toleration, and Moral Uncertainty, $1992 \mathrm{~S}$ Ct Rev 1, 27-28 (generally approving of Casey but lamenting the adoption of the "amorphous" undue burden standard). 
ysis of the undue burden standard in the abortion context is simply irrelevant to home schooling. In fact, however, the Supreme Court's decisions suggest that the two are not so different.

In Roe, the Court grounded the constitutional protection of abortion rights in the liberty guarantee of the Fourteenth Amendment's Due Process Clause and in a broader and more ill defined right of personal privacy. ${ }^{33}$ The Court surveyed precedents recognizing a zone of personal privacy and concluded that those cases "make it clear that the right has some extension to activities relating to marriage, procreation, contraception, family relationships, and child rearing and education." ${ }^{34}$ The Court has extended the protective "umbrella" of privacy rights to these five specific areas. In Casey, the joint majority reiterated the holdings of prior cases: "These [five] matters, involving the most intimate and personal choices a person may make in a lifetime, choices central to personal dignity and autonomy, are central to the liberty protected by the Fourteenth Amendment."35 Thus the Court has shown, through its explication of the constitutional privacy right, that abortion and home schooling do share a common jurisprudential ground.

A similar source of constitutional protection is not all that home schooling and abortion share. The conflicts between state and private interests in the home schooling context are analogous to those in the area of abortion regulation. States have a legitimate interest in the education of their citizens. To guard this interest, every state has enacted compulsory education laws, and many additionally regulate curriculum content, teacher certification, and the number of hours and days of instruction. It is parents, however, who largely retain responsibility for, and discretion over, the type and extent of education their children receive. And for a variety of reasons, including religious belief, dissatisfaction with public schools, and inability to pay for private education, an increasing number of parents are choosing to teach their children at home. ${ }^{36}$ These competing interests often collide as

33 410 US at $152-53$.

34 Id (emphasis added) (citing Loving $v$ Virginia, 388 US 1, 12 (1967) (marriage); Skinner $v$ Oklahoma, 316 US 535, 541-42 (1942) (procreation); Eisenstadt $v$ Baird, 405 US 438, 453-54 (1972) (contraception); Prince $v$ Massachusetts, 321 US 158, 166 (1944) (family relationships); Pierce $v$ Society of Sisters, 268 US 510, 534-35 (1925) (child rearing and education)).

${ }^{35} 112 \mathrm{~S}$ Ct at 2807. See also Runyon v McCrary, 427 US 160, 178 n 15 (1976) (stating that "[t]he Meyer-Pierce-Yoder 'parental' right and the privacy right ... may be no more than verbal variations of a single constitutional right").

36 See note 2 and accompanying text. 
home schooling parents struggle to meet demanding state regulations.

As in the abortion and other privacy right cases, the Court has recognized the conflict between private and state interests in the context of child rearing and education. It has at once provided broad protection for the private interests of parents in the education of their children, yet recognized that those rights are not unlimited in the face of important state interests.

\section{B. The Child Rearing and Education Landmarks}

Advocates of home schooling point to the "child rearing and education" portion of the privacy rights umbrella and argue that it is broad enough to encompass a parent's decision to teach her child at home. Their position is comparable to that of abortion rights advocates prior to Roe, when the Court had not yet passed on the constitutionality of abortion. In Roe, the Court found that the portions of the privacy rights umbrella dealing with contraception and procreation were broad enough to encompass a woman's decision to terminate her pregnancy. ${ }^{37}$

The Supreme Court case most frequently cited for protecting the interests of parents in guiding their children's education is the 1925 landmark, Pierce $v$ Society of Sisters. ${ }^{38}$ Indeed, both Roe and Casey refer to Pierce as the basis of the position that child rearing and education is a component of the privacy right. ${ }^{39}$ In Pierce, the Court struck down an Oregon law requiring every parent of a child between the ages of eight and sixteen to send the child to a public school. Invoking the liberty interest protected by the Due Process Clause, the Court held that the state law "unreasonably interfere[d] with the liberty of parents and guardians to direct the upbringing and education of children under their control. ${ }^{\prime 40}$ In what has become the most famous passage of the Pierce opinion, the Court elaborated: "The fundamental theory of liberty upon which all governments in this Union repose excludes any general power of the State to standardize its children by forcing them to accept instruction from public teach-

37410 US at $152-53$.

38 268 US 510 (1925).

39 See Roe, 410 US at 153; Casey, 112 S Ct at 2805.

10268 US at 534-35. See also Meyer $v$ Nebraska, 262 US 390, 391 (1923) (invalidating state restrictions on teaching languages other than English in private schools); Farrington $v$ Tokushige, 273 US 284, 298 (1927) (same). 
ers only. The child is not the mere creature of the State ...." ${ }^{\$ 1}$ Thus, Pierce stands for the proposition that parents have a constitutional right to educate their children in non-state-operated schools. ${ }^{42}$

Home schooling parents also frequently look to Wisconsin $v$ Yoder $^{43}$ for judicial support for the idea that private interests outweigh state interests in the education context. In Yoder, parents who were members of the Old Order Amish faith won the right to educate their children at home, despite Wisconsin's mandatory school attendance law. On the basis of the Free Exercise Clause of the First Amendment, the Court held that the Amish parents' belief that school attendance for their children beyond the eighth grade was contrary to their religion and way of life outweighed the state's interest in compulsory education. ${ }^{44}$ Transcending the specifically religious aspect of the claim in Yoder, the Court stated that "a State's interest in universal education, however highly we rank it, is not totally free from a balancing process when it impinges on fundamental rights and interests . . ." ${ }^{45}$ The fundamental right in Yoder was religious freedom. Nonetheless, as in Pierce, the Court prohibited the state interest from overcoming the right of parents to control the education of their children. ${ }^{46}$

Despite the seemingly broad power accorded private interests over state interests in these landmark child rearing and education cases, the very cases that grant protection to private interests also place limits on them. Pierce, for example, undeniably recognized and protected the state's interest in education: "No question is raised concerning the power of the State reasonably to regulate all schools ... [and] to require that all children of proper age attend some school ...." ${ }^{37}$ The state's power to impose "reasonable regulations" on the education of children was

${ }^{41} 268$ US at 535.

42 See Mark G. Yudof, David L. Kirp, and Betsy Levin, Educational Policy and the Law 16 (West, 3d ed 1992).

43406 US 205 (1972).

${ }^{44}$ Id at 214.

45 Id.

48 For further insight into the Court's view on the importance of parental control of their children's education, see Cook $v$ Hudson, 429 US 165, 166 (1976) (Burger concurring) ('Few familial decisions are as immune from governmental interference as parents' choice of a school for their children.... $)$.

47268 US at 534. 
reaffirmed in Yoder, as the Court strained to tailor its holding to the peculiar case of the Amish. ${ }^{48}$

Thus, as with the private right to abortion, the Court's decisions support a general protection of parents' privacy right to home school their children and to prevent the state from completely prohibiting this practice. However, the Court also clearly protects the state's interest in regulating education. The difficult question regarding home schooling regulations can thus be cast similarly to the one facing courts in the abortion context following Casey: How much of a burden on private rights is permissible?

C. The Appropriate Standard for Reviewing Home Schooling Regulations

When the Court in Casey changed the standard governing abortion regulations from strict scrutiny to the undue burden test, it moved away from a standard that favored private interests and restricted state actions, and embraced a standard that was intended to strike a more even balance between the competing interests in the area of abortion. Switching from rational basis review to the undue burden standard in the home schooling context would have the opposite effect. The shift would decrease state regulatory authority and provide greater protection to private interests. However, adopting the undue burden standard for home schooling would likewise have the effect of levelling the balance between the competing interests in this area.

The Court's education cases have maintained the state's prerogative to "reasonably regulate" parents' educational decisions for their children. Under the rational basis standard traditionally applied to home schooling cases, virtually all regulations have been deemed "reasonable." Under the undue burden standard, however, home schooling regulations would be judged by whether they create a "substantial obstacle" for parents wishing to teach their children at home.

In moving from the rational basis standard to the undue burden standard, a great many state home schooling regulations would still remain permissible. As the Casey joint majority held in applying the undue burden standard for the first time, only a narrow class of regulations, those that present a "substantial 
obstacle," fail to meet this test. ${ }^{49}$ In order to address the fears of the Casey dissenters, however, courts need specific guidance as to how they would apply the undue burden standard to home schooling regulations.

\section{Home Schooling Regulations and Their PuRPoses}

\section{A. The Ends and Means of Home Schooling Regulations}

In applying the undue burden standard to specific home schooling regulations, it is necessary to discern the state's legitimate interests in education before analyzing the propriety of its regulations. In Yoder, the Supreme Court identified the extent of the state's interest in requiring minimum levels of education: "[S]ome degree of education is necessary to prepare citizens to participate effectively and intelligently in our open political system ... [and to] prepare[] individuals to be self-reliant and selfsufficient participants in society. "W50 When the state aims to promote those goals, its education regulations-from compulsory attendance laws to private school regulations and home schooling restrictions-will be largely immune from constitutional challenge, even if challenged under a strict scrutiny standard.

There are five types of home schooling regulations. Broadly speaking, their requirements entail: (1) durational or minimumtime attendance by students; (2) state approval processes; (3) curriculum content; (4) teacher qualifications; and (5) student testing. ${ }^{51}$ These are the means, adopted in varying degrees and combinations, by which states safeguard their interest in education. And these are the obstacles that parents must overcome in order to teach their children at home and still remain in compliance with state compulsory attendance laws.

Some states employ straightforward durational requirements that specify the number of days and hours home-schooled children must be taught-sometimes exactly the same number as in public schools. ${ }^{52}$ Several states require government approval before allowing a child to be taught at home. Frequently, this involves only a simple process of reporting the situation to the

$49112 \mathrm{~S}$ Ct at 2820.

50406 US at 221.

51 See Brendan Stocklin-Enright, The Constitutionality of Home Education: The Role Of The Parent, The State and The Child, 18 Willamette L Rev 563, 588 (1982). Although Stocklin-Enright does not specifically classify student testing as a category of home schooling regulation, he discusses it in examples. See id at 592.

52 See, for example, Va Code $\$$ 22.1-254 (1993). 
state Department of Education or the local school board, and serves little more than an administrative function for the state. ${ }^{53}$

Other states require that private schools, including home schools, provide instruction "equivalent" to that in public schools. These states generally regulate curriculum content and prescribe that some or all of the subjects taught in public schools be taught in nonpublic schools. ${ }^{54}$

Teacher certification laws are a fourth category of home schooling regulation. They often specify a competency level for teachers in home schools and can require state certification. ${ }^{55}$ Finally, some states require that home-schooled children submit to periodic standardized achievement tests. ${ }^{56}$

B. Revisiting the Ends of Education Regulations: The OutcomeBased Approach

The "reasonable regulation" standard employed in Pierce and Yoder resembles the undue burden test. In determining whether state regulations are "reasonable," it is essential that their means and ends fit together. If the means adopted by a state go beyond those necessary to protect its legitimate interest, the regulation is not reasonable because it poses an undue burden on private interests.

Yoder outlines the state's general interest in an educated citizenry; however, in order to know whether a state education regulation goes too far, it is necessary to determine the precise contours of the state's interest in education. Shortly after Pierce, the Supreme Court decided a case that helps shed light on this inquiry. In Farrington $v$ Tokushige, the Court struck down a Hawaii regulation that severely restricted private schools in which instruction was given in a foreign language. ${ }^{57}$ The Farrington Court held:

[T] privately-supported schools where children obtain instruction deemed valuable by their parents and which is not obvi-

\footnotetext{
63 See, for example, Va Code $§ 22.1-254.1(B)$ (1993 \& Supp 1994).

at See, for example, Idaho Code $\S 33-202$ (1981 \& Supp 1994); Mich Comp Laws Ann $\S 380.1561(3)(a)$ (West 1988).

ss See, for example, Cal Educ Code $\$ 48224$ (West 1993); Ala Code $\$ 16-28-1$ (1)(a) (1988).

s6 See, for example, Ark Code Ann § 6-15-504(a) (Michie 1993).

57 273 US 284 (1927).
} 
ously in conflict with any public interest. [It] give[s] affirmative direction concerning the intimate and essential details of such schools, intrust[s] their control to public officers, and den[ies] both owners and patrons reasonable choice and discretion in respect of teachers, curriculum and text-books. Enforcement of the Act probably would destroy most, if not all, of them; and, certainly, it would deprive parents of fair opportunity to procure for their children instruction which they think important and we cannot say is harmful. ${ }^{58}$

The critical insight in this passage from Farrington is that the state's true interest lies in educational outcomes, not inputs. The state's interests, identified in Yoder as the development of self-reliant citizens who can effectively participate in the political process, ${ }^{59}$ are outcome-based objectives. Quite simply, the state's interest is not in the process of educating children, but in knowing that children are being educated. ${ }^{60}$ The state can guard its interests by ensuring that students outside of state-operated schools are, in fact, receiving the level of education deemed necessary by the state. As suggested in Farrington, this implies that the state's interest in educational inputs, such as curriculum content, teacher qualifications, duration, and the like, is minimal. Moreover, where the state interests are properly understood as outcome based, many input-based requirements become unreasonable.

Several types of state home schooling statutes regulate inputs. Most of these regulations have been upheld by the courts under the rational basis standard of review. Adherence to the outcome-based ends of the state's interest, however, is the key to the application of the undue burden standard and the analysis of whether regulations place a substantial obstacle in the way of parents.

68 Id at 298.

69 See text accompanying note 50 .

60 Note that this concept was not the creation of the Supreme Court. State provision of education did not become widespread until the mid-nineteenth century. At that time, the outcome-based conception of the state's interest in education was championed by the philosopher John Stuart Mill, among others. See On Liberty, in John Stuart Mill, Utilitarianism, Liberty, and Representative Government 216-18 (Dutton, 1950). 


\section{APPLYING THE UNDUE BURDEN STANDARD TO HOME SCHOOLING REGULATIONS}

Abortion opponents denounced Casey for the tentativeness of its step away from Roe. ${ }^{61}$ It is unclear exactly what effect the Casey standard will have on abortion decisions. ${ }^{62}$ However, it is clear that, after Casey, at least some previability abortion restrictions that would not have survived judicial scrutiny under Roe now will survive.

Similarly, moving from the rational basis standard to the undue burden standard in the home schooling context will not engender wholesale invalidation of state home schooling laws. Some classes of regulations will continue to satisfy judicial scrutiny under the undue burden standard, while others will not. In each case, this determination will rest upon the rationale of the outcome-based approach to state interests and the aim of the undue burden standard to more evenly balance state and private interests.

\section{A. Regulations That Survive under the Undue Burden Standard \\ Three decisions help illustrate the types of home schooling regulations that will continue to survive under the undue burden standard. In each case, the court upheld regulations that focused either exclusively or primarily on educational outcomes.}

\section{Standardized testing.}

Pursuant to the Arkansas Home School Act, home schooling parents must submit their children to standardized testing each year and to a minimum-performance test at age fourteen. ${ }^{63}$ In the 1988 case, Murphy $v$ Arkansas, parents challenged the testing requirement on several grounds, including the right of privacy. ${ }^{64}$

After noting that the Arkansas statute neither mandated teacher certification nor controlled curriculum content, the Eighth Circuit held that "the state must have a mechanism by which it can confidently and objectively be assured that its citi-

61 See Tamar Lewin, Long Battles Over Abortion Are Seen, NY Times A18 (June 30, 1992) (op-ed); Bork, NY Times at A19 (cited in note 32).

62 See Bigel, $18 \mathrm{U}$ Dayton $\mathrm{L}$ Rev at 762 (cited in note 15).

63 Ark Code Ann \$\$ 6-15-503-04 (1993).

64 F2d 1039, 1041 (8th Cir 1988). 
zens are being adequately educated. ${ }^{965}$ In rejecting the Murphys' challenge, the court concluded that "[t]he state's only safeguard to ensure adequate training of the home-schooled student is the standardized achievement test."

This case and its reasoning are perfectly supportable under the undue burden standard and the outcome-based approach. First, the Arkansas testing requirement places a minimal imposition on parents, demanding nothing of them before they proceed with a home schooling program. Requiring testing alone is far from the substantial obstacle necessary under the undue burden standard to render a regulation invalid. Second, the requirements of the statute are based solely on outcome-driven concerns. Testing requirements provide the state with a surveillance mechanism and say little about educational inputs. In fact, implicit in the Eighth Circuit's insistence that the state monitor the education of home-schooled students through standardized testing is a rejection of input-based control. As a result, this class of home schooling regulations provides little conflict with the private interest of parents in controlling their children's education. ${ }^{67}$

It is also worth noting how the undue burden standard would treat the state and private interests in Murphy. Though it is more deferential to private interests than the rational basis standard under which the Arkansas law was upheld, the undue burden standard still protects the state interest. Because it would have permitted the testing requirement, the undue burden standard would not have eliminated what the Eighth Circuit called "the state's only safeguard."

2. Reporting requirements.

The decision by the Maine Supreme Judicial Court in State $v$ $M c$ Donough ${ }^{69}$ illustrates a second class of home schooling regulations that would likely endure under the undue burden standard's scrutiny. At issue in $M c D$ onough was a statute allowing a home-education exception to the state's compulsory public school attendance law. ${ }^{70}$ The Maine rule required parents who

65 Id at 1042.

66 Id at 1042-43.

67 See Stocklin-Enright, 18 Willamette L Rev at 600 (cited in note 51).

852 F2d at 1042 .

69468 A2d 977 (Me 1983).

$7020 \mathrm{Me}$ Rev Stat Ann $\$ 911$ (Supp 1981-82), repealed and replaced by 20-A Me Rev Stat Ann § 5001-A (1993). 
wanted to home school their children to submit an instruction plan to their school district's board of directors for approval in order to take advantage of the public school attendance exception. ${ }^{71}$ The McDonoughs objected to the state approval process on Fourteenth Amendment Due Process grounds and refused to submit a home schooling proposal to the school board. ${ }^{72}$

The court upheld the Maine law, rejecting the McDonoughs' claim that the state had interfered with their right to educate their children as they saw fit. After pointing out that the statute acknowledged the right of parents to educate their children at home, the court upheld the provision because "[i]t defends against abuse of that right by requiring that parents obtain the approval of school officials .... ".73

When applying the undue burden standard to reporting requirements, it is important to identify the parents' objection precisely. The parents in McDonough objected to the state approval requirement per se, arguing that the state had no legitimate interest in knowing what their children were being taught. This attack goes directly to the state's outcome-based concerns. As discussed above, this category of home schooling regulation is designed to assist the state administratively; it says nothing about the educational inputs in home schools. ${ }^{74}$ Its existence poses no difficulty under the undue burden standard unless the approval process itself is so onerous that it deters parents from the home schooling option.

The application of the undue burden standard in Casey most analogous to the consideration of reporting requirements is the Court's treatment of the "informed consent" and waiting period feature of the Pennsylvania abortion law. That provision required a woman seeking an abortion to receive information about the nature of the procedure, the health risks involved, and the probable gestational age of the fetus, and then wait twenty-four hours before proceeding with the abortion. ${ }^{75}$

The Casey Court upheld that regulation under the undue burden standard. ${ }^{76}$ The joint majority noted the district court's findings that the mandatory twenty-four-hour waiting period

71 McDonough, 468 A2d at 979.

72 Id at $979-80$.

73 Id at 979.

74 See text accompanying note 53.

$7519 \mathrm{~Pa}$ Cons Stat Ann § 3205(a)(1).

${ }^{76}$ In so doing it overruled $A k r o n$, which had struck down a very similar regulation. See Casey, 112 S Ct at 2825. 
increased the cost and risk of delay for those women who have limited financial resources or who find it difficult to explain their whereabouts to their employers. Although the Court characterized these findings as "troubling," it nevertheless held that the waiting period did not on its face create a substantial obstacle to obtaining an abortion and did not therefore constitute an undue burden. ${ }^{77}$

Home school reporting and approval requirements present an analogous obstacle to those who wish to teach their children at home. The burden of producing a report will naturally fall hardest on those parents least able to afford it. Parents with lower levels of education might also find such requirements difficult hurdles to overcome. Nonetheless, these regulations cannot be said to present substantial obstacles on their face.

Like most testing requirements, approval regulations such as the Maine law in McDonough are generally narrowly tailored to serve the state's interest in compulsory education. Home schooling parents still retain great freedom under such regulations. Thus, where the law respects the balance between state and private interests, the undue burden standard will uphold the state interest even if some individuals might face greater obstacles to home schooling than others.

\section{On-site inspections.}

On-site inspections are a third type of regulation likely to receive the same treatment under the undue burden standard as under the rational basis standard. However, they present a harder case.

At issue in Blackwelder $v$ Safnauer was a New York school superintendent's policy of enforcing home schooling regulations through on-site visits by public school authorities. ${ }^{78}$ The regulations themselves were not especially onerous, featuring boilerplate language requiring that education be "substantially equivalent" to that in public schools and that instructors be "competent." The home schooling families claimed, however, that on-site inspections violated their rights to privacy and to direct their children's education..$^{80}$

77 Id.

78689 F Supp 106, 137 (N D NY 1988).

79 NY Educ Law § 3204(2) (McKinney 1981 \& Supp 1994).

so Blackwelder, 689 F Supp at 112. 
Before upholding the on-site inspections, the district court noted the uncertainty surrounding the proper method of analysis: "The degree of judicial scrutiny to be applied to a governmental action that interferes with the privacy interests recognized in Pierce . . . is not clear to this court." ${ }^{81}$ Nonetheless, the court upheld the superintendent's policy without reaching the issue of the proper standard of review. It found that the inspections served an important state interest and that they were minimally intrusive. ${ }^{82}$ The court placed significant weight on the fact that the visits in question were "infrequent, [ ] limited to the area in the home in which instruction is given, and [ ] conducted only at a mutually agreed upon time." ${ }^{\text {"83 }}$ In fact, the inspections were limited to "one or two" each school year. ${ }^{84}$

It is conceivable that on-site inspections, unlike testing and approval requirements, could present a substantial obstacle to home schooling parents. Furthermore, overly recurrent and demanding inspections could be viewed as a disguised state effort to regulate educational inputs. However, on the facts of Blackwelder, the undue burden standard would uphold this New York home schooling policy.

Many home schooling advocates would likely find such inspections highly objectionable. However, a judicial approach that struck down such a mild imposition on private interests would not be sufficiently attuned to the state/private balance sought by the undue burden standard. Here, the occasional on-site inspections serve a surveillance function similar to achievement testing requirements. Although they intrude on parents' privacy interests more than testing, the inspections do not reach the substantial obstacle level. While it is true that testing is more narrowly tailored to serve state interests and more clearly outcome based, the undue burden standard permits states to pursue their legitimate interests in any manner that does not place a substantial obstacle in the way of home schooling parents. One or two inspections per year cannot reasonably be said to deter parents from the home schooling option.

81 Id at 136. See also id at 137 n 34 (citing State $v$ Shaver, 294 NW2d 883 (ND 1980) (applying rationality analysis); Care \& Protection of Charles, 399 Mass 324, 504 NE2d 592 (1987) (applying a heightened level of scrutiny)).

82 Blackwelder, 689 F Supp at 141-42.

s3 Id at 141.

${ }^{84}$ Id at 113. 
B. Regulations That Would Not Survive under the Undue Burden Standard

If the courts move from the rational basis standard to the undue burden standard in the education context, not all home schooling regulations will survive judicial scrutiny. Two classes of regulations that are especially suspect under the undue burden standard are teacher-certification and curriculum-content requirements.

\section{Teacher certification.}

The regulation of home school teachers is problematic for two reasons. First, unlike other categories of regulation, teacher qualification requirements are particularly input based. The Farrington Court specifically cited parental discretion with respect to teachers as an intimate and essential detail of private education, the denial of which was invalid. ${ }^{85}$ Teacher regulations are centrally concerned with the manner in which knowledge is imparted and less so with the actual product of home schooling. As such, they do more than simply safeguard the state's legitimate interest in education.

Second, teacher certification requirements pose a much greater obstacle to home schooling than other types of regulation. When the Court struck down the spousal notification section of the Pennsylvania abortion law in Casey, it distinguished this provision from the sections it upheld on the ground that spousal notification did "not merely make abortions a little more difficult or expensive to obtain"; rather, notification was likely altogether to prevent a significant number of women from obtaining an abortion. ${ }^{86}$ Similarly, teacher certification requirements can pose unusually strong and sometimes insurmountable obstacles to home schooling parents. Most parents are not certified teachers. Thus, where certification requirements mandate the completion of programs designed for professional educators, this type of regulation can amount to a de facto prohibition of home schooling.

Two teacher certification cases, one an older Califormia case and one decided last year in Michigan, present the problem. In both cases, the courts applied rational basis analysis and upheld

\footnotetext{
85 273 US at 298.

B6 $112 \mathrm{~S} \mathrm{Ct}$ at 2829.
} 
the regulations. However, it is likely that neither regulation would survive under the undue burden standard.

In the California case, In re Shinn, a couple was prevented from home schooling their three children because they were not certified teachers. ${ }^{87}$ The governing regulation was a section of the California Education Code that permitted an exception to the state's public school attendance requirement only for children educated in private full-time day schools or by private tutors holding valid state teaching credentials. ${ }^{88}$

The court had little trouble upholding the provision under rational basis scrutiny. It found that California's educational program was designed "to promote the general welfare of all the people," and that the teacher certification requirement was a reasonable regulation in support of this program. ${ }^{89}$ However, the facts of the case and the arguments marshalled by the state indicate that the provision would not withstand the undue burden standard.

Neither the parents nor the children in Shinn were typical home schoolers. The parents were a veterinary doctor and a musician, and the three children, ages ten, twelve, and thirteen, were above-average students in their public school classes. ${ }^{90} \mathrm{Dr}$. Shinn removed his children from the public schools because he was dissatisfied with the education they were receiving and began teaching them himself at home through a high school correspondence course. ${ }^{91}$ Pursuant to a state investigation, a welfare worker visited the Shinn home and "found the children to be well and in fine physical condition." ${ }^{.92}$ And at trial the Shinns presented a doctor's report pronouncing the children well ahead of their peers in academic achievement. ${ }^{93}$

Even though it was obvious that the educational outcome produced by the Shinns' home schooling was sufficient to meet any reasonable state objective, the state convinced the court that its input-based teacher certification regulations were crucial because "[h]ome education, regardless of its worth, is not the

67195 Cal App 2d 683, 16 Cal Rptr 165, 167-68 (1961).

B3 Cal Educ Code $\S 12155$ (1959), superseded by Cal Educ Code $\S 48224$ (West 1993).

89 16 Cal Rptr at 174-75.

90 The youngest, John, was allowed to skip third grade because of his performance. The middle child, Barbara Ann, placed 64th out of 339 students taking the sixth grade Metropolitan achievement test. And the eldest, Mary Elizabeth, skipped seventh grade, and ranked 47th out of 290 older eighth graders. Id at 169.

91 Id at 169-70.

92 Id at 170 .

${ }^{23}$ Id at 172. 
legal equivalent of attendance in school in the absence of instruction by qualified private tutors. Accordingly,... the Shinn children [are] not being instructed... by persons capable of teaching." ${ }^{\text {"In }}$ In an unequivocal rejection of the Shinns' claim, the court added: "Proof of proper instruction and study would be no defense to a prosecution for neglecting and refusing to send children to public school [or the equivalents outlined in the statute]."95

The nature of the requirement in Shinn illustrates the manner in which input-based regulations extend the reach of the state beyond its legitimate interests. In Shinn, the state did not simply pursue its interest in an educated citizenry but instead specifically targeted the educational process. On the facts of Shinn, this was arguably contrary to the furtherance of the educated-citizenry interest. At the same time, the regulation completely trampled the private rights of the Shinns in the protected area of child rearing and education. Thus, the California teacher certification regulation would fail under the undue burden standard: it presents a substantial obstacle to home schooling parents, it is input based, and it accords nearly complete deference to state interests over private interests.

The 1993 Michigan Supreme Court teacher certification case, People $v$ Bennett ${ }^{96}$ presents the clearest case in which adoption of the undue burden standard would reverse the outcome of a home schooling decision. Bennett presented a direct Fourteenth Amendment challenge to Michigan's teacher certification requirement on the ground that it impermissibly impeded the right of parents to direct their child's education. ${ }^{97}$ The suit challenged the Michigan Department of Education's guidelines for educating children in the home, one of which required that all instruction be given by a state-certified teacher. ${ }^{98}$

The Bennett family fit the typical home schooling profile. The parents, dissatisfied with Detroit's public schools, withdrew their four children in the belief that they could provide a better education for the children themselves. Unable to afford to send their

94 Id at 173.

95 Id at 172.

96442 Mich 316, 501 NW2d 106 (1993).

97 Id at 110.

98 Id at 109 n 7, citing the Michigan Department of Education's home schooling guidelines, Education of the Child in the Parental Home, which were derived from Mich Comp Laws Ann § 380.1532(1) (West 1988 \& Supp 1994). 
children to a parochial school, ${ }^{99} \mathrm{Mr}$. and Mrs. Bennett home schooled their children for one year prior to the litigation, enrolling them in a commercial home-based education program. ${ }^{100} \mathrm{At}$ the end of the school year, standardized achievement tests indicated that three of the four Bennett children exhibited educational development at or above their grade levels, and the fourth, whose performance had fallen while attending public school, had made steady progress toward his proper grade level during the year at home. ${ }^{101}$

The Michigan Supreme Court majority first dispensed of the Bennetts' argument that they had a fundamental right to educate their children at home free from government interference. Citing the "reasonable regulation" language from Pierce, the majority rather easily dismissed the Bennetts' claim for strict scrutiny review. ${ }^{102}$ The court then noted that "the state's teacher certification requirement need only satisfy the minimal scrutiny test."103 While there is no doubt that the court applied the rational basis standard correctly-it held that the teacher certification requirement was "not an unreasonable way to further the state's interest"104 - the Bennett case illustrates how an intermediate standard would provide greater protection for private interests while still safeguarding those of the state.

Unlike Shinn, Bennett contained a vigorous dissenting opinion that set forth the objections to the use of the rational basis standard in this context. In his dissent, Justice Riley grasped Farrington's input/outcome distinction, arguing that "the state possesses a legitimate interest in the manner of education only as long as it is reasonably related to educational achievement." $105 \mathrm{He}$ then cogently captured the overextension of the state's interest and the submergence of the private interest, noting that "the state failed to provide any evidence proving a correlation between the teacher certification requirement and educational achievement, while the Bennetts have proven that their children have been adequately educated without certified teach-

99 $501 \mathrm{NW} 2 \mathrm{~d}$ at $108 \mathrm{n} 3$.

100 The home-based education program was sponsored by Clonlara, Inc., of Ann Arbor, Michigan. The program provided a comprehensive curriculum, teacher guides, and standardized achievement tests. See id at 109 .

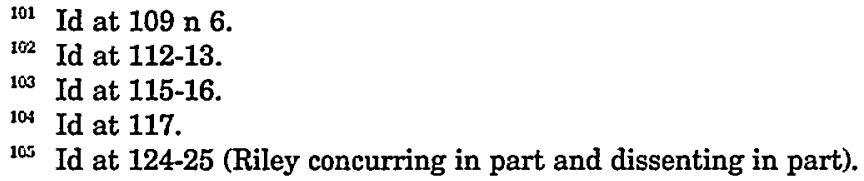


ers." ${ }^{106}$ Finally, the dissent correctly explained that such onerous restrictions undermine protections offered in the Pierce line of cases: "the teacher certification requirement attempts to standardize the education of the Bennett children to state-imposed dictates in derogation of parents' constitutional rights."107 The Bennett dissent should not be mistaken for a critique merely of the majority's application of the rational basis standard. It is a condemnation of the use of the standard itself where there are compelling private interests at stake and the state has surpassed its legitimate interests. ${ }^{108}$

A proper conception of the undue burden standard would require reversal of Bennett. As noted above, the noncoercion doctrine underlying the Casey standard signifies that the state may regulate abortion but may not prohibit it or make it substantially more difficult to obtain. ${ }^{109}$ The Michigan teacher certification requirement violates this noncoercion principle. Parents who fail to comply with the teacher certification requirement are forced to send their children to inadequate public schools even if they have successfully taught them at home. The application of the undue burden standard to these regulations would avoid such a senseless result by sustaining parents' ability to teach their children, subject only to the preservation of the state's ability to monitor the children's academic progress.

\section{Curriculum content.}

Like teacher certification requirements, curriculum content regulations present substantial obstacles and restrict educational inputs. The conflict over curriculum is even more acute, however, because dissatisfaction with public school curricula is frequently parents' precise motivation for choosing home schooling. If, for example, parents are compelled to use the very same textbooks that are used in public schools under the guise of ensuring that the children receive an "equivalent education," the state has effectively vetoed the parents' decision to teach their children at home. ${ }^{110}$ Such an obstacle clearly constitutes an undue burden.

106 Id at 125-26.

107 Id at 126.

${ }^{108}$ Indeed, Justice Riley urged the adoption of strict scrutiny in this case and in private and home school cases generally. See id at 123-24 n 10.

109 See text accompanying note 27.

110 See Dwight Edward Tompkins, An Argument For Privacy In Support Of The Choice Of Home Education By Parents, 20 J L \& Educ 301, 317 (1991). 
However, the state's interest in curriculum content means that the undue burden standard cannot be applied as easily here as it can be to teacher certification requirements. At one level, curriculum requirements are surely input based. Indeed, Farrington cited the choice of curriculum and textbooks as an intimate and essential detail of a school over which parents retain "reasonable choice and discretion." At another level, though, state regulation of curricula is closely linked to educational outputs. For example, if the state considers it essential that primary school children have a basic knowledge of arithmetic, and that secondary school children learn algebra, then requiring home schools to include math in their curricula is an attempt to pursue those outcomes. Most home schoolers would have little quarrel with those requirements, and they would therefore present no real obstacle. However, a simple substitution of the word "evolution" for "arithmetic" or "algebra" above demonstrates the difficulty of resolving these cases.

The undue burden standard would force courts to make the difficult distinction between curriculum requirements that pose a substantial obstacle to home schooling parents and those that do not. For example, while it is not hard to see how an evolution requirement might present a substantial obstacle to some parents, a state requirement that mathematics be a part of home school curricula could theoretically present an equally insurmountable obstacle to the unusual parent who perceived no value in her child learning that subject. Although the search for a distinction between these two requirements might be lacking in principle, it is really no different from Casey's differentiation between a twenty-four-hour waiting period and a spousal notification requirement. In both instances, the evolution and spousal notification provisions present a greater obstacle to a greater number of people and therefore more dramatically shift the balance of competing interests in favor of the state.

This distinction can be made meaningful in the home schooling context by recalling that both Pierce and Yoder recognize that the state retains the power to reasonably regulate schools despite parents' protected right to raise and educate their children. ${ }^{112}$ Determining which features of a curriculum regulation are reasonable can take two forms. One approach would examine regula-

111273 US at 298.

112 See text accompanying notes $38-48$. 
tion of the instruments of instruction, textbooks for example, and the other would differentiate between academic subjects.

Requiring that home schooling parents instruct their children from specified textbooks ${ }^{113}$ is a purely input-based regulation and is therefore highly suspect under the undue burden standard. This requirement almost completely precludes parents' ability to make innovative choices. Furthermore, this type of regulation not only presents an undue burden, but also is an affront to Pierce because it arguably makes the child "the mere creature of the State."114 The undue burden standard, therefore, can be seen to serve as a proxy for Pierce in the home schooling context. A regulation requiring home schools to conform to the specific processes of the public schools does not allow for parental discretion in any real sense.

A reasonable regulation in this area could set standards for curricula without specifying texts. For instance, the state could require that children be instructed in reading and American history, yet leave the choice of the instruments of instruction to parents. Such a regulation would survive under the undue burden standard because it protects the state's interest in educational standards (outputs) without destroying parental discretion over the specific subjects with which to accomplish the educational goal (inputs). ${ }^{115}$ If the state finds through an output-based measurement like a standardized test that a student's performance is unacceptably low, it may then reasonably inquire into the parents' inputs, such as the quality of the textbooks they are using.

The second approach to determining the reasonableness of a curriculum regulation would examine whether requiring the teaching of certain subjects in itself poses an undue burden. Some states require that home schooling programs include instruction in all subjects taught in public schools. ${ }^{116}$ These laws restrict parental discretion just as much as textbook mandates do. Such blanket requirements are not necessary to meet what the Court in Yoder identified as the state's interest: ensuring that

${ }^{113}$ For an example of such a regulation, see Ky Rev Ann Stat $\S 158.080$ (1992). The Kentucky Supreme Court struck down this requirement on the ground that it violated the Kentucky Constitution. Kentucky State Board for Elementary \& Secondary Education $v$ Rudasill, 589 SW2d 877 (Ky 1979).

114 See text accompanying note 41.

115 For a discussion of this aspect of curriculum content regulations, see StocklinEnright, 18 Willamette L Rev at 589-98 (cited in note 51).

116 See, for example, Idaho Code § 33-202; Mich Comp Laws Ann § 380.1561(3)(a). 
citizens are prepared to participate effectively in the political process and to be self-reliant members of society. ${ }^{117} \mathrm{~A}$ court applying the undue burden standard to this type of statute would have to attempt the inexact determination of which subjects were necessary to fulfill the state's interest and which were superfluous. ${ }^{118}$

Some might object to according this degree of discretion to the courts. Indeed, this is one of the inherent weaknesses of the undue burden standard. The Casey majority, however, did not seem troubled by this defect when it applied the standard to the protected right to abortion. A court's calculation with respect to home schooling should not be different.

C. A Glimpse at the Undue Burden Standard Applied to Home Schooling: Care \& Protection of Charles

Any attempt to apply an existing standard to a new context is necessarily speculative, especially when the standard in question has been used only once before. The Supreme Judicial Court of Massachusetts, however, provided a glimpse of how a court should apply the Casey undue burden standard to the home schooling context. Without reference to an intermediate standard of review, the Massachusetts high court, in the 1987 case of Care \& Protection of Charles, ${ }^{119}$ engaged in an analysis of home schooling regulations very similar to the one future courts would employ in applying the undue burden standard.

The facts of Charles are typical of home schooling cases. The parents ${ }^{120}$ sought to home school their children, but refused to comply with the Massachusetts reporting requirement. ${ }^{121}$ While the constitutionality of this requirement was actually the only question in the case, the opinion went much further than was necessary merely to dispose of that issue. After remanding the case, the court opted to provide the lower court with "guidance on the extent to which approval of a home school proposal may be conditioned on certain requirements without infringing on the

117406 US at 221. See also text accompanying note 50.

118 See Tompkins, $20 \mathrm{~J} \mathrm{~L} \&$ Educ at 318 (cited in note 110) (distinguishing subjects vital to good citizenry and child welfare); Stocklin-Enright, 18 Willamette L Rev at 604-06 (cited in note 51) (arguing that the state can require only subjects necessary to safeguard its interest in the franchise).

119399 Mass 324, 504 NE2d 592 (1987).

120 The names of the parents and children involved in this case were withheld.

121 Mass Ann Laws ch 76, § 1 (Law Co-op 1991). 
liberty interests of the parents under the Fourteenth Amendment."122

The first example of the undue burden approach in Charles occured when the court limited state interests to outcome-based objectives: "the State interest . . . lies in ensuring that the children residing within the State receive an education, not that the educational process be dictated in its minutest detail. ${ }^{\text {123 }}$ Next, the court upheld the relatively nonintrusive reporting requirement on the ground that "[w]ithout such an approval process, the State would be powerless to assert its interest in the case of a child [who is being home schooled]."124 As discussed above in regard to McDonough, the undue burden standard does not prohibit such measures, which safeguard the state's interest in compulsory education without subjecting the parents to a substantial obstacle. ${ }^{125}$

Before offering the lower court specific guidance on the parameters of permissible home school regulations, the court cautioned the school committee responsible for setting approval criteria that it had to limit its requirements to those that were essential to the State's interest in ensuring that all children are being educated. ${ }^{126}$ This warning is the precise basis upon which the state interest side of the undue burden standard is premised.

The specific guidance offered to the lower court looks very much like undue burden analysis. With respect to teacher requirements, the court held that the school committee could examine the competency of parents to teach, but rejected any certification rule or requirement that parents have a college or advanced academic degree. ${ }^{127}$ While this position recognizes that at some level teacher or parent incompetence can impair the state's interest in education, it also prohibits the substantial obstacle that formal certification and educational proficiency requirements pose for many parents.

With respect to curriculum requirements, the court held that the state could have access to the textbooks and lesson plans parents used. Although this allowance seems intrusive, the court ordered that the access be limited to the state's surveillance

${ }^{122}$ Charles, 504 NE2d at 600.

${ }^{123}$ Id.

$124 \mathrm{Id}$.

${ }^{125}$ See text accompanying notes 69-77. In fact, the Charles opinion cited McDonough on this point. See 504 NE2d at 600 .

125 Id.

127 Id at 601. 
concern. It concluded that "[the] school committee may not use this access to dictate the manner in which the subjects will be taught. This would involve the school authorities in an activity beyond the legitimate scope of the State interest involved."12s Although the curriculum requirement here is a regulation of educational input, the undue burden standard would nevertheless normally permit it so long as it did not present a substantial obstacle to parents. Such an obstacle would exist if the state prescribed a set of subjects that parents had to teach in a rigid, nondiscretionary manner. The Charles opinion forbids that, however, and hence follows the reasoning of the undue burden standard yet again.

The Charles court also suggested that the state would be free to require periodic standardized testing of home-schooled children to ensure that they were progressing satisfactorily and meeting minimum standards. ${ }^{129}$ As this Comment has shown, such testing requirements are easily supportable under the undue burden standard.

\section{CONCLUSION}

The analysis undertaken in Charles gives courts some direction in applying the undue burden standard to future home schooling cases. It also illustrates some of the benefits and drawbacks of applying Justice O'Connor's standard to home schooling.

As shown by the Charles dicta, the undue burden standard does provide a more even balance between state and private interests than does the rational basis standard. In the home schooling context, that means parents would receive greater constitutional protection. As a result, the undue burden standard would align home schooling jurisprudence with the decree of the child rearing and education precedents: namely, that parents have a constitutionally protected right in this area, subject only to state regulation that is reasonable.

However, as with all applications of intermediate standards of review, the Charles opinion exhibits the fine distinctions more typically associated with, and perhaps more properly left to, social policy and the legislative process. Justice Scalia's fear that the Casey standard will conceal raw judicial policy choices is as applicable to home schooling as it is to abortion.

\footnotetext{
123 Id at 602 .

129 Id.
} 
Whatever its merits, the undue burden standard cannot precisely demarcate the point at which a state home schooling regulation becomes a substantial obstacle to parents. Though home schooling parents would celebrate the adoption of an intermediate standard more protective of their right to educate their children, their enthusiasm should be tempered by the recognition that the precise scope of their rights under the new standard, though expanded, would still largely be left to the vagaries of judges. 